\title{
New horizons for treating castration resistant prostate cancer: Bipolar Androgen Therapy
}

\author{
Novos horizontes para o tratamento do câncer de próstata resistente à castração: \\ Terapia Androgênica Bipolar
}

Pedro Henrique Isaacsson Velho', Katia Regina Marchetti², Gabriel Passos Souza ${ }^{2}$

\begin{abstract}
The treatment of metastatic prostate cancer has evolved over the decades focusing on manipulation of the androgen receptor pathway with or without chemotherapy. Despite new drugs discovered with incrementing survival benefits, the disease continues to be fatal after development of castration resistance and progression on abiraterone and enzalutamide. In this context, attempts of androgen pathway manipulation have led to the development of the Bipolar Androgen Therapy (BAT), which consists of a rapid transition from a castration state to supraphysiologic levels of testosterone and then back to castration levels. Pilot studies have shown this strategy to be safe and supported the development of further clinical trials. Phase II trials have demonstrated PSA response and disease control in a significant number of patients, including a possible resensitizing effect to enzalutamide. This promising strategy may in the future become another available option for these patients.
\end{abstract}

Keywords: Prostatic Neoplasm; Castration-Resistant; Testosterone; Prostate-Specific Antigen

1. Johns Hopkins Sidney Kimmel Comprehensive Cancer Center, Johns Hopkins University, Baltimore, MD, USA.

2. Serviço de Oncologia Clínica - Instituto do Câncer do Estado de São Paulo (ICESP), São Paulo, SP, Brasil.

Financial support: none to declare.

Conflicts of interest: Pedro Henrique Isaacsson Velho has the following conflicts of interest: Honorary: Bayer. Speakers' Bureau: AstraZeneca, Pfizer, Bristol-Myers Squibb. Research Funding: Bristol-Myers Squibb, Pfizer. Expert Testimony: Bayer. Travel, Accomodations, Expenses: AstraZeneca, Astellas Pharma, Pfizer, Merck Serono, MerckDescriptors: Prostatic Neoplasm, castration-resistant, Testosterone, Prostate-specific antigen. Correspondence author: Pedro Isaacson Velho. Sidney Kimmel Comprehensive Cancer Center, Johns Hopkins University. Skip Viragh Building, Floor 9 , 201 North Broadway, Baltimore, Maryland Zip Code: 21287. USA. E-mail: pisaacs4@jhmi.edu. Phone: +1 410-955-8893 (Clinic) +1 410-614-7287 (Fax) 


\section{RESUMO}

O tratamento do câncer de próstata metastático tem evoluído ao longo das décadas focando na manipulação da via do receptor de andrógeno, com ou sem quimioterapia. Apesar das novas drogas descobertas com incremento dos benefícios de sobrevivência, a doença continua a ser fatal após o desenvolvimento da resistência à castração e à progressão da abiraterona e da enzalutamida. Neste contexto, tentativas de manipulação de vias androgênicas levaram ao desenvolvimento da Terapia Bipolar de Andrógênos (BAT), que consiste em uma transição rápida de um estado de castração para níveis suprafisiológicos de testosterona e depois de volta aos níveis de castração. Estudos piloto mostraram que esta estratégia é segura e apoiaram o desenvolvimento de novos ensaios clínicos. Ensaios de Fase II demonstraram resposta do PSA e controle da doença em um número significativo de pacientes, incluindo um possível efeito de ressensibilização à enzalutamida. Essa estratégia promissora pode, no futuro, tornar-se outra opção disponível para esses pacientes.

Descritores: Neoplasias da Próstata; Resistente à Castração; Testosterona; Antígeno Prostático Específico

\section{INTRODUCTION}

Prostate cancer (PCa) is the second most common cancer in men worldwide. In the United States, it has an incidence of approximately 161,000 new cases per year, being responsible for 26,000 deaths. In Brazil, annually 72,000 new cases are diagnosed and approximately 17,000 deaths occur because of this disease $^{(1,2)}$ the American Cancer Society estimates the numbers of new cancer cases and deaths that will occur in the United States in the current year and compiles the most recent data on cancer incidence, mortality, and survival. Incidence data were collected by the Surveillance, Epidemiology, and End Results Program; the National Program of Cancer Registries; and the North American Association of Central Cancer Registries. Mortality data were collected by the National Center for Health Statistics. In 2017, 1,688,780 new cancer cases and 600,920 cancer deaths are projected to occur in the United States. For all sites combined, the cancer incidence rate is $20 \%$ higher in men than in women, while the cancer death rate is $40 \%$ higher. However, sex disparities vary by cancer type. For example, thyroid cancer incidence rates are 3 -fold higher in women than in men (21 vs 7 per 100,000 population. The treatment for localized PCa include active surveillance, radiotherapy or surgery, and the 5-year survival rate approaches 100\%.(1,3,4) In metastatic disease, androgen deprivation therapy (ADT) alone or in combination with chemotherapy ${ }^{(4,5)}$ or both to first-line long-term hormone therapy in prostate cancer (STAMPEDE or abiraterone $\mathrm{e}^{(6,7)}$ is the backbone of the initial treatment.

Since 1941, when Huggins and Hodges demonstrated that PCa has an intrinsic dependence on androgens by reducing serum androgen concentrations (either by orchiectomy or exogenous estrogen ad- ministration), therapy based on androgen deprivation became the pillar of treatment in advanced disease. Unfortunately, many patients with metastatic disease develop castration-resistant prostate cancer (mCRPC), defined as disease progression despite low serum testosterone levels. Even after several advances in the last decade with the approval of numerous medications which demonstrated overall survival (OS) improvements (docetaxel, ${ }^{(8)}$ sipuleucel-T, ${ }^{(9)}$ cabazitaxel,(10) abiraterone, ${ }^{(11)}$ enzalutamide ${ }^{(12)}$ and radium-223, ${ }^{(13)}$ median OS still averages 2 to 3 years after the tumor becomes resistant to ADT. ${ }^{(14,15)}$

In the last decade, it has become clear that the androgen receptor (AR) signaling remains crucial for PCa progression from a hormone-sensitive state to a castration-resistant state. There are several mechanisms of androgen resistance in response to treatment with ADT, affecting every portion of the AR signaling axis, such as AR overexpression, gene amplification and mutations, and expression of ligand-independent AR splice variants. ${ }^{(16)}$ In addition to these AR mechanisms of resistance, the intracrine and paracrine production of androgens, or the conversion of weak androgens in potent androgens (such as dihydrotestosterone) can continue to drive the tumor despite low serum testosterone.(16)

The different mechanisms of resistance to androgen deprivation therapy may represent cancer vulnerabilities' and therapeutic opportunities. In the setting of AR overexpression, the administration of testosterone to achieve supraphysiologic serum concentrations has paradoxally been shown to have the capacity to cause death of prostate cancer cells by different mechanisms of action. (17-21) This finding has created the hypothesis that high-doses of testosterone followed by a state of androgen deprivation, entitled bi- 
polar androgen therapy (BAT) could potentially serve as a therapeutic strategy for men with advanced PCa. This innovative treatment proved that can overcome hormone resistance and resensitize cancer to AR-targeted therapies. In this review we will explore the use of testosterone as treatment of PCa.

\section{BIPOLAR ANDROGEN THERAPY - RATIONALE AND PRE-CLINICAL STUDIES}

\section{Rationale and pre-clinical studies}

\section{Cell Cycle Action}

During prostatic carcinogenesis, the AR acquires an oncogene gain of function with regard to DNA replication licensing. Malignant prostate cells need this transformed gene to proliferate, and during progression on ADT, meaning the development of resistance to hormone deprivation, the AR adaptive protein expression increases massively ( $>50-100$ fold). ${ }^{(16,22)}$ During early G1 phase of the cell cycle, nuclear AR binds to DNA, a required step for licensing DNA replication during the S-phase. Throughout cell cycle progression, AR remains associated with DNA until late mitosis when, as a DNA licensing factor, it must be removed via its degradation and the re-licensing can occur in the next cell cycle. After administration of supraphysiologic testosterone levels, increased ligand stabilizes the link between DNA and AR, preventing $A R$ degradation. This phenomenon inhibits DNA re-licensing, resulting in cell death in the subsequent cell cycle ${ }^{(17,23)}$ (Figure 1).

\section{DNA double-strand breaks}

New data have shown that the administration of high androgen concentrations induce double strand (DSB) DNA breaks in PCa cells, leading to chromo- somal rearrangements such as the TMPRSS2-ERG fusion. (24) This mechanism also may explain how supraphysiologic doses of testosterone inhibits cancer cell proliferation. Furthermore, some studies have shown that androgen signaling pathway involves the co-recruitment of AR and topoisomerase II beta (TOP2B), being responsible for TOP2B-mediated DNA DSB. This phenomenon occur at regulatory regions of AR target genes in PCa cells. ${ }^{(24)}$ Analogous finding, showing that estrogen signaling pathway involves the co-recruitment of estrogen receptor TOP2B to estrogen receptor target sites, inducing transient DNA DSB, was also found in breast cancer cells. ${ }^{(25)}$ The intrinsic relationship between high androgen levels and TOPB2 provided the rationale for the first "modern" clinical trial, which evaluated therapeutic sypraphisiologic testosterone (Bipolar Androgen Therapy - BAT) in addition to oral etoposide (a topoisomerase inhibitor). This combination has been chosen to provide synergistic activity between these two therapies. ${ }^{(26)}$

A clinical case report recently published described an extreme response to BAT in a patient with germline mutations in the homologous recombination (HR) genes BRCA2 and ATM.(27) This report corroborated the rationale that supraphysiologic doses of testosterone can cause DNA DSB, and possibly may have an addictive effect in patients with somatic and/ or germline DNA repair defects, especially in patients with abnormalities in the HR pathway.

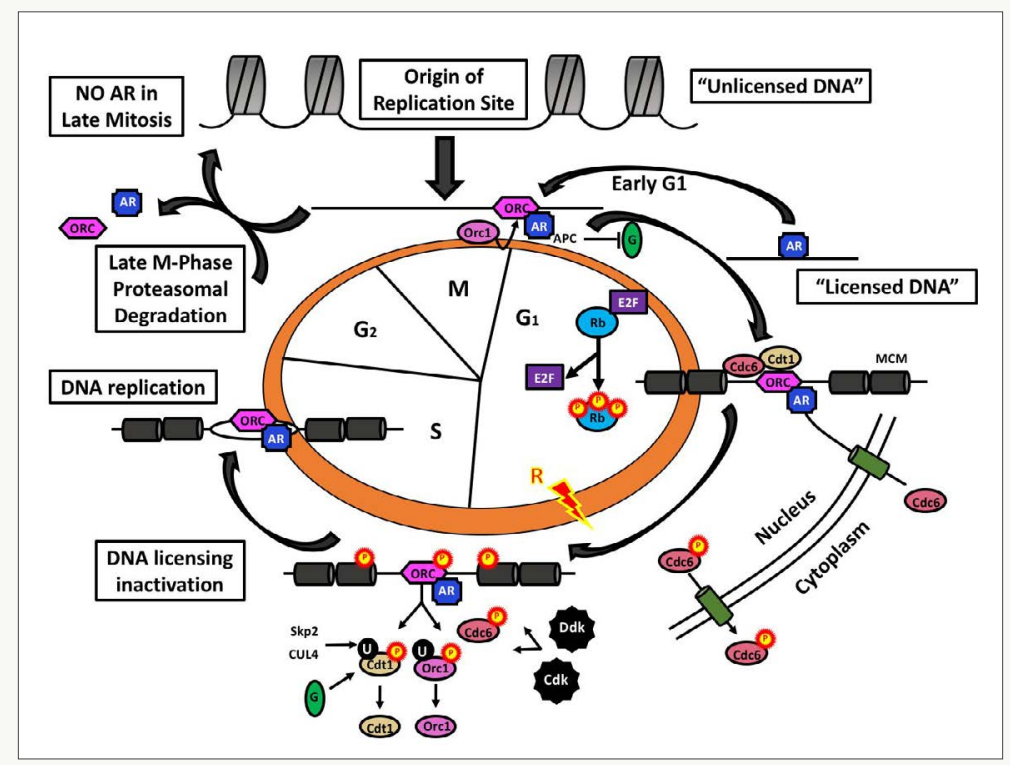

Figure 1. Rationale of Bipolar Androgen Therapy ${ }^{(23)}$ 


\section{CLINICAL STUDIES}

The BAT approach was first tested in a pilot study ${ }^{(26)}$ in patients with asymptomatic CRPC. In this trial, BAT treatment was associated with oral etoposide, based on the rationale that high-dose testosterone could generate transient DNA DSB in CRPC cells through the recruitment of $A R$ and TOP2B in response to androgen elements. ${ }^{(24,28)}$ This study enrolled 16 patients to initially receive testosterone cypionate $400 \mathrm{mg}$ intramuscularly on day 1 and oral etoposide $100 \mathrm{mg}$ on days 1 to 14 of each cycle, repeating cycles every 28 days. ${ }^{(26)}$ This dose and formulation of testosterone was chosen because it produces supraphysiologic testosterone levels (>1500 ng/mL) within the first days after injection and a subsequent decline to normal testosterone levels after 2 weeks, returning to near-castrate testosterone levels by 28 days. ${ }^{(29)}$ This study demonstrated that BAT associated with etoposide was active in $\mathrm{PCa}$, showing a decline in PSA in 50\% (7/14) of patients, with $28.6 \%$ (4/14) having a PSA decline $\geq 50 \%$ (PSA50 response). Of the ten patients who had evaluable soft tissue metastases, $50 \%$ had radiographic responses: 4 partial responses (PR), 1 complete response (CR) and $30 \%$ had stable disease (SD). It is important to notice that only $20 \%$ of patients had progressive disease, but no patient developed urinary obstruction, new or worsening pain, or skeletal events, demonstrating that this therapy was safe in patients with metastatic disease. The majority of side effects were caused by etoposide, including nausea, fatigue, alopecia, edema and neutropenia.

A different trial evaluated BAT alone in two cohorts of patients: asymptomatic metastatic PCa or biochemical recurrent disease (elevated PSA with no evidence of metastatic disease). ${ }^{(30)}$ All patients were hormone-naïve, meaning that prior therapy with ADT or a second line hormonal agent was not allowed. After enrollment, patients received 6-month of ADT and those with PSA response (defined in the study as a PSA $<4 \mathrm{ng} / \mathrm{ml}$ or decline $\geq 50 \%$ below baseline at the end of this six months period) started BAT. Of the 29 patients who initiated the BAT phase of the study, 59\% (17/29) achieved a PSA $<4 \mathrm{ng} / \mathrm{mL}$ after 18-month of treatment period, the primary endpoint of the study; and $89.6 \%(26 / 29)$ had a PSA below their pre-treatment baseline. Despite numerically different, no statistically significant difference in PSA response was seen between patients with BCR vs patients with asymptomatic metastatic disease (42\% vs. $71 \%$, respectively; $p=0.119)$. Also, of the 10 patients who had evaluable disease, $80 \%(8 / 10)$ had objective responses per RECIST. ${ }^{(30)}$

Recently it was published the results of a phase II single-arm trial which evaluated BAT in asymptomatic or minimally symptomatic MCRPC patients who had progressed on enzalutamide.(31) Patients could have received previous docetaxel (for hormone-sensitive disease), radium-223, abiraterone and/or sipuleucel-T. The study enrolled 30 patients to receive BAT, all of them had progressed on enzalutamide therapy and 43\% (13/30) had progressed to both enzalutamide and abiraterone. ${ }^{(31)}$ After progression on BAT, patients were rechallenged with enzalutamide. The study met its two co-primary endpoints, the PSA50 response rate for BAT and for enzalutamide rechallenge. The PSA50 response rate was 30\% (95\% $\mathrm{Cl} 15$ - 49; $p<0.0001$ ) for patients receiving BAT and $52 \%$ for patients who were rechallenged to enzalutamide, after progression on BAT (95\% Cl 33 - 71; $\mathrm{p}<0.0001)$. Twelve patients had measurable lesions and six (50\%) achieved PR or CR by RECIST (95\% CI 21 - 79) (31)and paradoxically, rapid cycling between high and low serum testosterone concentrations (bipolar androgen therapy [BAT]. These trials are outlined in table 1.

These studies also evaluated the impact of BAT in quality of life (Qol) metrics, comparing questionnaires answers at baseline, during BAT and after returning to ADT. A portion of patients presented with restored erectile function based upon International Index of Erectile Function (IIEF), besides an improve-

Table 1. Clinical trials evaluating BAT in PCa

\begin{tabular}{|c|c|c|c|c|c|c|}
\hline $\begin{array}{l}\text { Name/ } \\
\text { Author }\end{array}$ & Inclusion Criteria & Therapies & Design/Phase & $\mathrm{N}$ & PSA response & $\begin{array}{l}\text { Radiologic } \\
\text { response } \\
\text { (CR+PR) }\end{array}$ \\
\hline $\begin{array}{l}\text { Schweizer } \\
\text { et al. }\end{array}$ & Asymptomatic CRPC & BAT + Oral Etoposide & $\begin{array}{c}\text { Single-arm } \\
\text { phase I/II }\end{array}$ & 16 & PSA50: $28.6 \%$ & $50 \%$ \\
\hline BATMAN & $\begin{array}{c}\text { Asymptomatic meta- } \\
\text { static mHSPC or bio- } \\
\text { chemical recurrent } \\
\text { disease }\end{array}$ & BAT & $\begin{array}{l}\text { Single-arm } \\
\text { Phase II }\end{array}$ & 29 & $\begin{array}{c}\mathrm{PSA}< \\
\text { 4ng/mL: } 59 \%\end{array}$ & $80 \%$ \\
\hline $\begin{array}{l}\text { Teply } \\
\text { et al. }\end{array}$ & $\begin{array}{l}\text { Asymptomatic or } \\
\text { minimally symp- } \\
\text { tomatic mCRPC who } \\
\text { had progressed on } \\
\text { enzalutamide }\end{array}$ & $\begin{array}{c}\text { BAT + Rechallenged } \\
\text { with enzalutamide } \\
\text { after progression on } \\
\text { BAT }\end{array}$ & $\begin{array}{l}\text { Single-arm } \\
\text { Phase II }\end{array}$ & 30 & $\begin{array}{l}\text { PSA50: } 30 \% \\
\text { Enzalutamide } \\
\text { rechallenge } \\
\text { PSA50: } 52 \%\end{array}$ & $50 \%$ \\
\hline
\end{tabular}

CRPC: castration-resistant prostate cancer; mHSPC: metastatic hormone-sensitive prostate cancer; PSA50: Decline of 50\% or more in PSA; CR: Complete response; PR: Partial response 
ment in lipid profile and glycemic control. Other Qol metrics, however, did not show differences from baseline. Patients also presented with weight gain and acute increases in hemoglobin level and hematocrit. In essence a better metabolic profile was achieved among patients treated with BAT. ${ }^{(31,32)}$

Relevant side effects are summarized in table 2 and presented essentially as grade 1 and 2 toxicities. The most common side effect of BAT reported in clinical trials were musculoskeletal pain, fatigue, hot flashes, edema and elevation in hemoglobin levels. Serious adverse events seen were non-ST segment elevation myocardial infarction, pulmonary embolism and urinary obstruction; and perhaps they are not truly related to testosterone administration. There was a concern for flare phenomenon and caution should be advised for patients with potential for urinary obstruction and critical bone lesions ${ }^{(26,31,32)}$ all men develop resistance to primary castrating therapy and secondary androgen deprivation therapies (ADTs; however, worsening pain, urinary obstruction and hematuria after initiation of BAT were rarely reported (Table 2). Also, no treatment related deaths were reported, which allowed further studies to be developed, with three ongoing phase II clinical trials addressing BAT in different clinical settings and combinations. (Table 3)

Table 2. BAT side effects

\begin{tabular}{|c|c|c|c|}
\hline Name & Teply et al. & BATMAN & Schweizer et al. \\
\hline Musculoskeletal pain & $40 \%$ & $7 \%$ & $0 \%$ \\
\hline HGB elevation & $37 \%$ & NR & NR \\
\hline Hypertension & $23 \%$ & NR & NR \\
\hline Breast Tenderness & $17 \%$ & NR & $25 \%$ \\
\hline Fatigue & $17 \%$ & $10 \%$ & $56.3 \%$ \\
\hline Nausea & $17 \%$ & NR & NR \\
\hline Gynecomastia & $13 \%$ & NR & NR \\
\hline Hot Flashes & $13 \%$ & $52 \%$ & NR \\
\hline Edema & $10 \%$ & $38 \%$ & $50 \%$ \\
\hline Urinary Obstruction & $3 \%$ & NR & $0 \%$ \\
\hline Hematuria & NR & $2 \%$ & $0 \%$ \\
\hline
\end{tabular}

HGB: hemoglobin; NR: not reported

Table 3. Ongoing trials evaluating BAT in PCa

\begin{tabular}{|c|c|c|c|c|c|}
\hline Name & Therapies & Design/Phase & $\mathrm{N}$ & Endpoints & NCT Number \\
\hline RESTORE & $\begin{array}{l}\text { BAT Cohort A: pa- } \\
\text { tients who had pro- } \\
\text { gressed on enzalut- } \\
\text { amide (Published) } \\
\text { Cohort B: patients } \\
\text { who had progressed } \\
\text { on abiraterone } \\
\text { Cohort C: patients } \\
\text { who had progressed } \\
\text { on ADT only }\end{array}$ & $\begin{array}{l}\text { Single arm } \\
\text { Phase II }\end{array}$ & 90 & $\begin{array}{l}\text { Primary: PSA response to } \\
\text { BAT, PSA response to abi- } \\
\text { raterone or enzalutamide } \\
\text { after BAT. } \\
\text { Secondary: Time to PSA } \\
\text { progression on enzalutamide } \\
\text { or abiraterone or return to } \\
\text { castrate levels of testoster- } \\
\text { one post-BAT; Time to PSA } \\
\text { progression on BAT, ORR, } \\
\text { Time to docetaxel chemo- } \\
\text { therapy. }\end{array}$ & NCT02090114 \\
\hline TRANSFORMER & BAT vs Enzalutamide & $\begin{array}{c}\text { Random- } \\
\text { ized Phase } \\
\text { II }\end{array}$ & 180 & $\begin{array}{l}\text { Primary: PFS } \\
\text { Secondary: PSA response, } \\
\text { ORR, Time to PSA Progres- } \\
\text { sion, PSA response rate to } \\
\text { enzalutamide post-BAT, QoL, } \\
\text { rPFS. }\end{array}$ & NCT02286921 \\
\hline COMBAT Trial & BAT + Nivolumab & Phase II & 44 & $\begin{array}{l}\text { Primary: PSA response } \\
\text { Secondary: rPFS, ORR, OS. }\end{array}$ & $X X X X X$ \\
\hline
\end{tabular}




\section{CASE REPORTS}

Here we report two case reports of patients who had great responses to BAT therapy in the context of castrate resistant disease.

Patient 1 is a 69-year-old man who was diagnosed with adenocarcinoma of the prostate and underwent radical retropubic prostatectomy in 2007. He eventually developed biochemical recurrence and received treatment for biochemical recurrent prostate cancer with intermittent luteinizing hormone-releasing hormone agonist (LHRH), bicalutamide and ketoconazole. Unfortunately, he was diagnosed with $\mathrm{MCRPC}$ and received ad first line treatment enzalutamide. In 2015 at the time of progression on enzalutamide his PSA rose (PSA $=9.5 \mathrm{ng} / \mathrm{ml}$ ) and a CT scan showed some enlarging pelvic adenopathies (Figure 2: target lesion $=3.4 \times 2.2 \mathrm{~cm}$ on axial image). His bone scan was not suggestive of metastatic bone disease.

The patient was enrolled in a clinical trial to receive BAT and was initiated on treatment in March 2015. In this study, BAT was testosterone cypionate $400 \mathrm{mg}$ intramuscularly every 28 days and continuous LHRH agonist therapy. After two months his PSA level became undetectable and after five months CT scan showed a major improvement of his pelvic adenopathy, showing only a subcentimetric node. (Figure 2) Besides that, he had a rise in his hemoglobin level from baseline which was sustained (from $15.1 \mathrm{~g} / \mathrm{dL}$ to $17.2 \mathrm{~g} / \mathrm{dL}$ ). Patient remains with no evidence of disease on CT scan, with a stable PSA level of $0.6 \mathrm{ng} /$ $\mathrm{ml}$, with excellent treatment tolerance for at least 3 years of treatment, and his last follow up was in June 2018. (Graphic 1)

Patient 2. is a 74 year-old man with mCRPC. He presented with a Gleason $7(4+3)$ disease, initially treated with radical prostatectomy. He eventually developed biochemical recurrence and metastatic disease in retroperitoneal lymph nodes and underwent treatment with continuous LHRH agonist therapy, enzalutamide and Sipuleucel-T sequentially. In August 2014 a CT scan showed progressive retroperitoneal adenopathy (Figure 3: right para-aortic lymph node $=2.4 \mathrm{~cm}$ in short dimension) and a rising PSA. (From $29.8 \mathrm{ng} / \mathrm{ml}$ to $50.9 \mathrm{ng} / \mathrm{mL}$ ). His bone scan was not suggestive of metastatic bone disease.

The patient discontinued enzalutamide and was enrolled in a clinical trial with BAT on October 2014. In this study BAT also was testosterone cypionate 400 mg intramuscularly every 28 days and continuous LHRH agonist therapy. After two months the patient presented with important decrease in PSA (PSA = 0.7 $\mathrm{ng} / \mathrm{mL}$ ) and radiographic PR (Figure 3). However, response was not sustained and he presented with rising PSA levels and radiographic disease progression, with BAT being discontinued in June 2015 (PSA = 11.8 $\mathrm{ng} / \mathrm{mL}$ ) when enzalutamide was re-initiated as part of the study protocol. After two months he presented with decrease in PSA (PSA $=3.8 \mathrm{ng} / \mathrm{mL}$ ), which was not sustained, presenting with a rising PSA in December 2015 (PSA = $23.6 \mathrm{ng} / \mathrm{mL})$. He resumed BAT in February 2016, which he received for two months with initial, but not sustained PSA decline. He developed progressive disease and was taken off from the trial on July 2016. (Graphic 2)

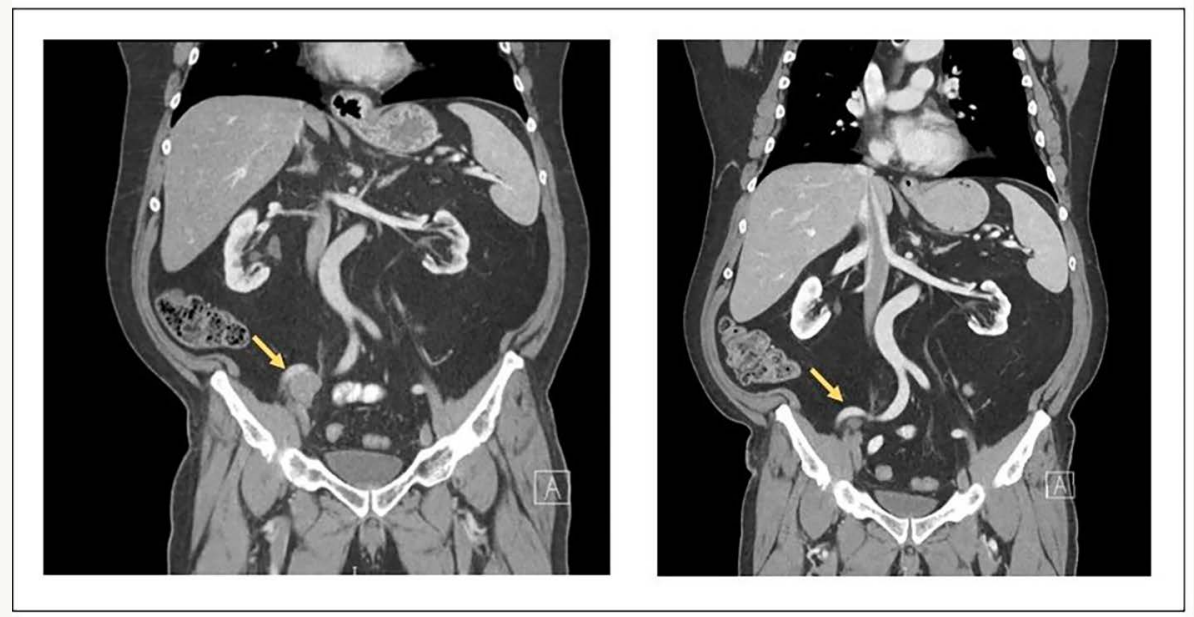

Figure 2. Radiographic Response to Bipolar Androgen Therapy - patient 1 


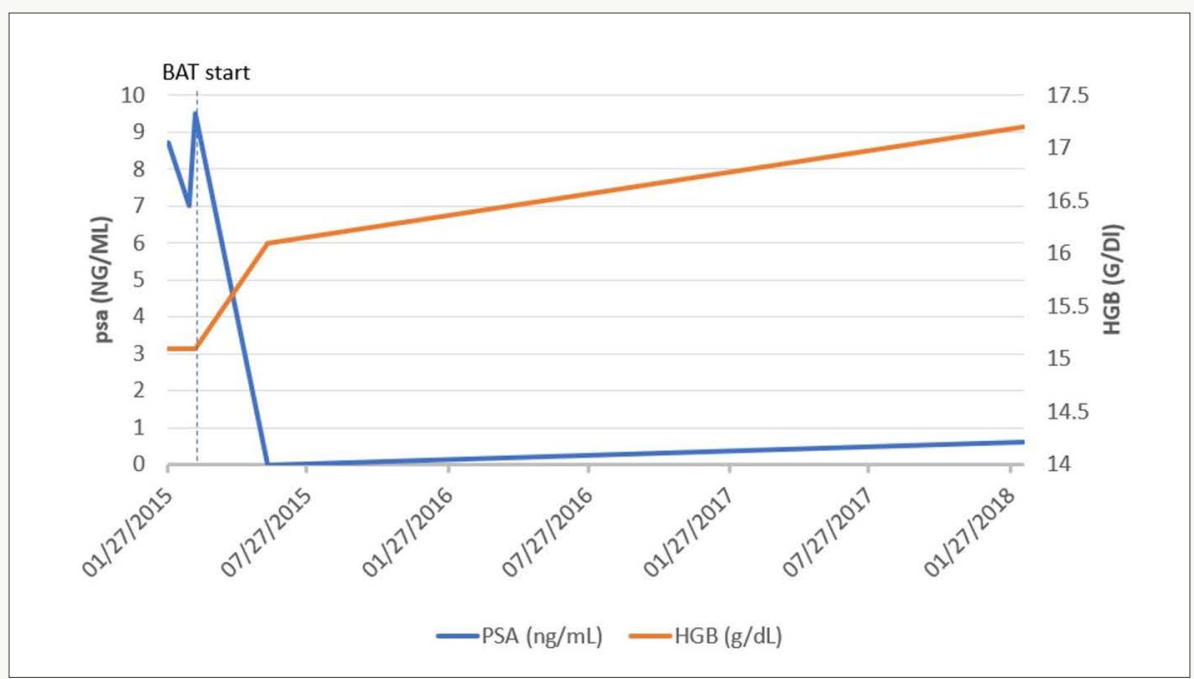

Graphic 1. PSA and HGB evolution for patient 1

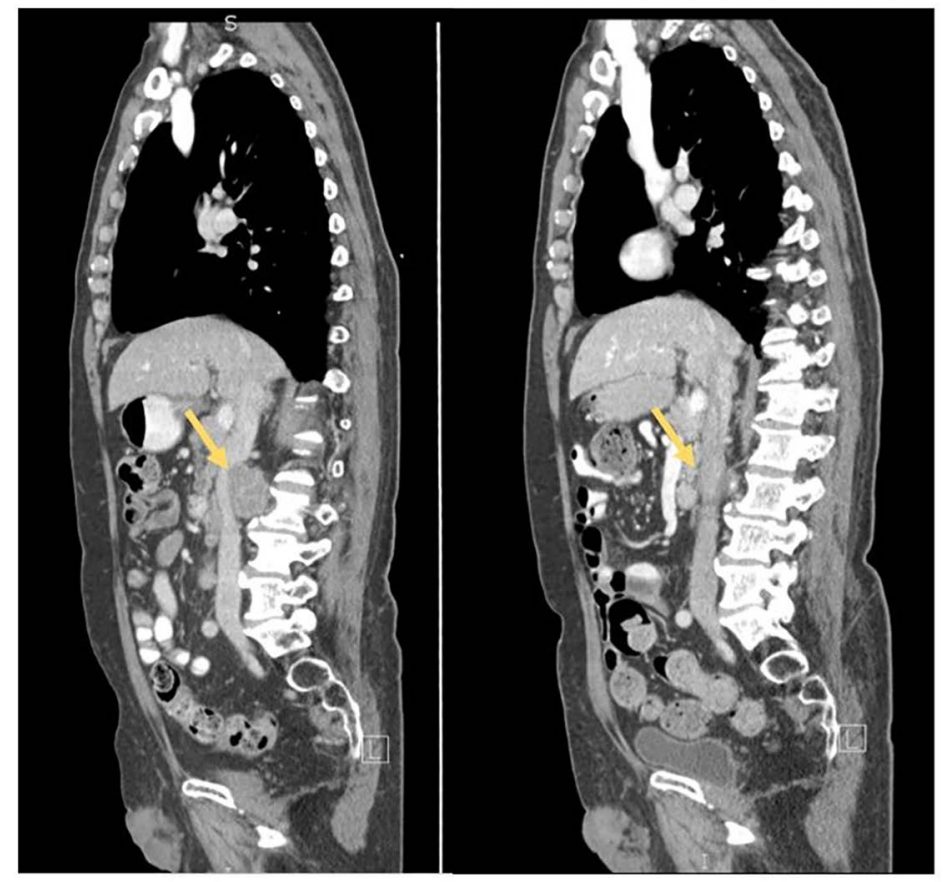

Figure 3. Radiographic Response to Bipolar Androgen Therapy - patient 2 


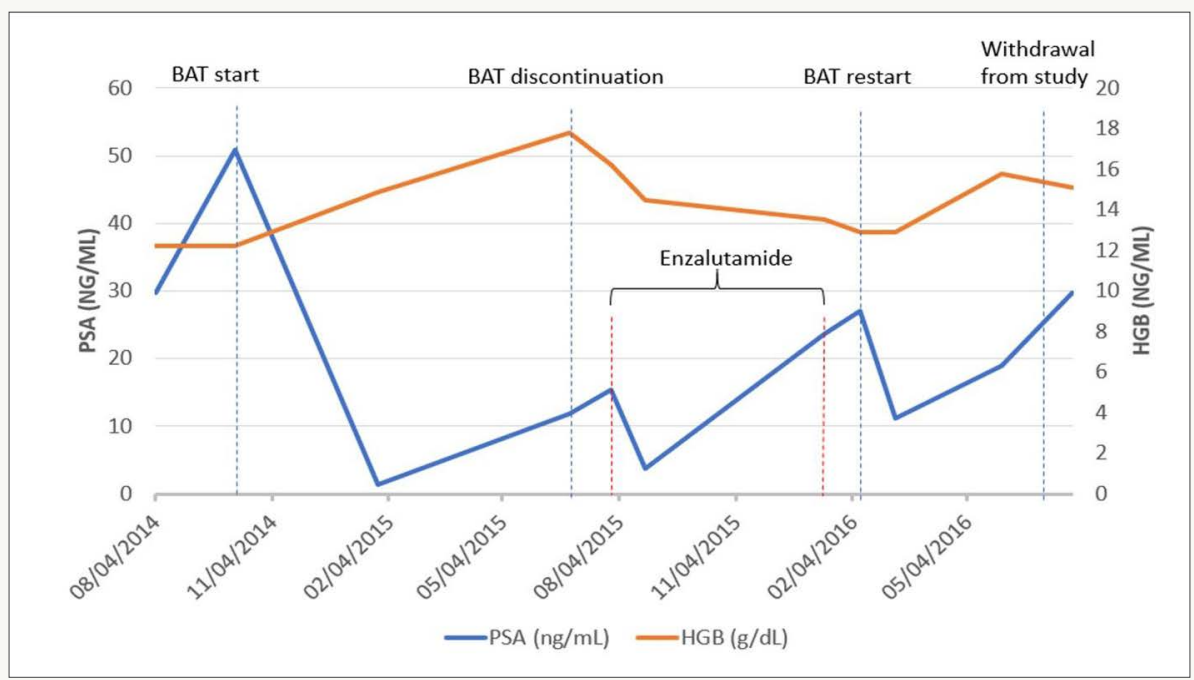

Graphic 2. PSA and HGB evolution for patient 2

\section{PERSPECTIVES/CONCLUSION}

The hallmark of oncogenesis and cancer progression in PCa is the androgen signaling axis, composed by the AR and androgens. Despite AR signaling continues to drive cancer progression, even after castration-resistant disease, novel approaches to target the AR and its pathway benefit patients. This approach has led FDA to approve three agents based on this rationale (abiraterone, enzalutamide and apalutamide). ${ }^{(33-35)}$ However, the benefit of these AR-targeted therapies is limited, and rarely lasts for long time, especially in castration-resistant disease. In this setting, BAT has shown promising activity not only for PSA and radiographic responses, but for its capacity to resensitize tumors to AR-targeted therapies $^{(31)}$ and paradoxically, rapid cycling between high and low serum testosterone concentrations (bipolar androgen therapy [BAT], which is unprecedented in $\mathrm{PCa}$. This phenomenon can provide several new innovative approaches to treat this disease, alternating therapies to provide, during BAT, high-testosterone levels, and subsequently very-low testosterone levels, returning to AR-targeted therapies after progression on BAT. It is reasonable to believe that this "on-off" treatment approach can potentially provide benefit for patients, however, despite promising, this rationale should be tested in clinical trials.

BAT could have its efficacy potentiated by several mechanisms. The addition of therapies with different mechanisms of action, complementary and synergic to BAT, could hypothetically enhance the effectiveness of this approach. One of the mechanisms by which BAT has its action occur during the transition from the G1 to the S-phase of the cell cycle, ${ }^{(17)}$ therefore, therapies which act in the cell cycle could provide synergistic effect to BAT. The cyclin-dependent kinases (CDKs) inhibitors, small-molecules which inhibit different checkpoints of the cell cycle, have demonstrated activity in several types of malig- nancies, especially in breast cancer, another disease driven by hormone receptor. ${ }^{(36)}$ Based on the rationale of this class of drug, perhaps the association of CDK inhibitors and BAT could improve the results of the hormonal modulation alone in patients with $\mathrm{PCa}$. Nonetheless, clinical trials are needed to confirm this hypothesis.

Also, by causing DSB in DNA, BAT could be associated with therapies that impair DNA repair mechanisms, causing cell death by the synthetic lethality principle.(37) The Poly (ADP-ribose) polymerase (PARP) inhibitors impair base excision repair mechanism, a well-known mechanism of DNA repair, causing genomic instability and enhancing sensitivity to DNA-damaging agents. This mechanism explains why this class of drug, when administered in patients who harbor somatic and/or germline DNA repair defects (such as abnormalities in homologous recombination genes), causes death of cancer cells. Analogously, BAT can cause DNA damage by DSBs, and the association with PARP inhibitors could enhance the genomic instability and impair the alternative mechanisms of DNA repair, potentially improving the efficacy of this approach. This mechanism also supports the hypothesis why patients harboring mutations in DNA repair pathway genes may be particularly sensitive to BAT.(27) Further studies to test this hypothesis combining BAT and PARP inhibitors are also needed.

The DNA damage caused by BAT approach, leading to genomic instability, might create new antigens and perhaps increase the mutational load, a well-known factor that can increase the efficacy of immunotherapy. Based on this rationale, a clinical trial called COMBAT (NCT03554317) was designed to evaluate if the combination of a checkpoint inhibitor and BAT could potentiate the efficacy of this therapy and provide long-term benefit for patients. This trial will combine nivolumab, a PD-1 inhibitor, and BAT for patients with $\mathrm{MCRPC}$. 
To summarize, BAT has demonstrated in several clinical trials to be a promising therapy for MCRPC. Perhaps intermittent therapy with BAT followed by antiandrogens can increase the time on treatment of patients, and maybe improve the outcomes. Also, it has shown as the only proved strategy which can resensitize $\mathrm{mCRPC}$ to antiandrogens (e.g. enzalutamide). Because of these impressive results, it should be explored in different settings and combinations, such as with CDK inhibitors, PARP inhibitors or immunotherapies. To conclude, we believe that more options for treatment, using BAT as backbone, will become available in the coming years, and they will have a crucial role in the better understanding and in the treatment of PCa.

\section{REFERENCES}

1. Siegel RL, Miller KD, Jemal A. Cancer Statistics, 2017. CA Cancer J Clin. 2017;67(1):7-30.

2. Brasil. Ministério da Saúde. INCA - Instituto Nacional de Câncer - Estimativa 2018 [Internet]. [cited 2018 Mar 8]. Available from: http://www. inca.gov.br/estimativa/2018/

3. Cooperberg MR, Carroll PR. Trends in Management for Patients With Localized Prostate Cancer, 1990-2013. JAMA. 2015;314(1):80-2.

4. Sweeney CJ, Chen YH, Carducci M, Liu G, Jarrard DF, Eisenberger $M$, et al. Chemohormonal Therapy in Metastatic Hormone-Sensitive Prostate Cancer. N Eng J Med. 2015;373(8):737-46.

5. James ND, Sydes MR, Clarke NW, Mason MD, Dearnaley DP, Spears MR, et al.; STAMPEDE investigators. Addition of docetaxel, zoledronic acid, or both to first-line long-term hormone therapy in prostate cancer (STAMPEDE): survival results from an adaptive, multiarm, multistage, platform randomised controlled trial. Lancet. 2016;387(10024):1163-77.

6. Fizazi K, Tran N, Fein L, Matsubara N, Rodriguez-Antolin A, Alekseev BY, et al.; LATITUDE Investigators. Abiraterone plus Prednisone in Metastatic, Castration-Sensitive Prostate Cancer. N Eng J Med. 2017;377(4):352-60.

7. James ND, de Bono JS, Spears MR, Clarke NW, Mason MD, Dearnaley DP, et al.; STAMPEDE Investigators. Abiraterone for Prostate Cancer Not Previously Treated with Hormone Therapy. N Eng J Med. 2017;377(4):338-51.

8. Tannock IF, de Wit R, Berry WR, Horti J, Pluzanska A, Chi KN, et al.; TAX 327 Investigators. Docetaxel plus Prednisone or Mitoxantrone plus Prednisone for Advanced Prostate Cancer. N Eng J Med. 2004;351(15):1502-12.

9. Kantoff PW, Higano CS, Shore ND, Berger ER, Small EJ, Penson DF, et al.; IMPACT Study Investigators. Sipuleucel-T immunotherapy for castration-resistant prostate cancer. N Engl J Med. 2010;363(5):411-22.
10. de Bono JS, Oudard S, Ozguroglu M, Hansen S, Machiels JP, Kocak I, et al.; TROPIC Investigators. Prednisone plus cabazitaxel or mitoxantrone for metastatic castration-resistant prostate cancer progressing after docetaxel treatment: a randomised open-label trial. Lancet. 2010;376(9747):1147-54.

11. de Bono JS, Logothetis CJ, Molina A, Fizazi K, North S, Chu L, et al.; COU-AA-301 Investigators. Abiraterone and increased survival in metastatic prostate cancer. N Engl J Med. 2011;364(21):1995-2005.

12. Scher HI, Fizazi K, Saad F, Taplin ME, Sternberg CN, Miller K, et al.; AFFIRM Investigators. Increased survival with enzalutamide in prostate cancer after chemotherapy. N Engl J Med. 2012;367(13):1187-97.

13. Parker C, Nilsson S, Heinrich D, Helle SI, O'Sullivan JM, Fosså SD, et al.; ALSYMPCA Investigators. Alpha emitter radium-223 and survival in metastatic prostate cancer. N Eng J Med. 2013;369(3):213-23.

14. Tannock IF, de Wit R, Berry WR, Horti J, Pluzanska A, Chi KN, et al.; TAX 327 Investigators. Docetaxel plus Prednisone or Mitoxantrone plus Prednisone for Advanced Prostate Cancer. N Eng J Med. 2004;351(15):1502-12.

15. Oudard S, Fizazi K, Sengeløv L, Daugaard G, Saad F, Hansen S, et al. Cabazitaxel Versus Docetaxel As First-Line Therapy for Patients With Metastatic Castration-Resistant Prostate Cancer: A Randomized Phase III Trial-FIRSTANA. J Clin Oncol. 2017;35(28):3189-97.

16. Watson PA, Arora VK, Sawyers CL. Emerging mechanisms of resistance to androgen receptor inhibitors in prostate cancer. Nat Rev Cancer. 2015;15(12):701-11.

17. Denmeade SR, Isaacs JT. Bipolar androgen therapy: the rationale for rapid cycling of supraphysiologic androgen/ablation in men with castration resistant prostate cancer. Prostate. 2010;70(14):1600-7. 
18. Kokontis JM, Lin HP, Jiang SS, Lin CY, Fukuchi J, Hiipakka RA, et al. Androgen suppresses the proliferation of androgen receptor-positive castration-resistant prostate cancer cells via inhibition of Cdk2, CyclinA, and Skp2. PLoS One. 2014;9(10):e109170.

19. Umekita Y, Hiipakka RA, Kokontis JM, Liao S. Human prostate tumor growth in athymic mice: inhibition by androgens and stimulation by finasteride. Proc Natl Acad Sci U S A. 1996;93(21):11802-7.

20. Chuu C, Hiipakka RA, Fukuchi J, Kokontis JM, Liao S. Androgen causes growth suppression and reversion of androgen-independent prostate cancer xenografts to an androgen-stimulated phenotype in athymic mice. Cancer Res. 2005;65(6):2082-4.

21. Chuu CP, Kokontis JM, Hiipakka RA, Fukuchi J, Lin HP, Lin CY, et al. Androgens as therapy for androgen receptor-positive castration-resistant prostate cancer. J Biomed Sci. 2011;18:63.

22. Chen CD, Welsbie DS, Tran C, Baek SH, Chen R, Vessella $\mathrm{R}$, et al. Molecular determinants of resistance to antiandrogen therapy. Nature Med. 2004;10(1):33-9.

23. Isaacs JT, Brennen WN, Denmeade SR. Rationale for bipolar androgen therapy (BAT) for metastatic prostate cancer. Cell Cycle. 2017;16(18):163940.

24. Haffner MC, Aryee MJ, Toubaji A, Esopi DM, Albadine R, Gurel B, et al. Androgen-induced TOP2B-mediated double-strand breaks and prostate cancer gene rearrangements. Nat Gen. 2010;42(8):668-75.

25. Ju BG, Lunyak VV, Perissi V, Garcia-Bassets I, Rose DW, Glass CK, et al. A topoisomerase Ilbeta-mediated dsDNA break required for regulated transcription. Science. 2006;312(5781):1798-802.

26. Schweizer MT, Antonarakis ES, Wang $\mathrm{H}, \mathrm{Aji}-$ boye AS, Spitz A, Cao H, et al. Effect of bipolar androgen therapy for asymptomatic men with castration-resistant prostate cancer: results from a pilot clinical study. Sci Transl Med. 2015;7(269):269ra2.

27. Teply BA, Kachhap S, Eisenberger MA, Denmeade SR. Extreme Response to High-dose Testosterone in BRCA2- and ATM-mutated Prostate Cancer. Eur Urol. 2017;71(3):499.
28. Haffner MC, De Marzo AM, Meeker AK, Nelson WG, Yegnasubramanian S. Transcription-induced DNA double strand breaks: both oncogenic force and potential therapeutic target? Clin Cancer Res. 2011;17(12):3858-64.

29. Behre HM, Nieschlag E. Testosterone preparations for clinical use in males. In: Nieschlag $E$, Behre HM, eds. Testosterone: Action, Deficiency, Substitution. Cambridge, UK: Cambridge University Press; 2012. p. 309-35.

30. Schweizer MT, Wang $H$, Luber B, Nadal R, Spitz A, Rosen DM, et al. Bipolar Androgen Therapy for Men With Androgen Ablation Naïve Prostate Cancer: Results From the Phase II BATMAN Study. Prostate. 2016;76(13):1218-26.

31. Teply BA, Wang $H$, Luber B, Sullivan R, Rifkind I, Bruns $A$, et al. Bipolar androgen therapy in men with metastatic castration-resistant prostate cancer after progression on enzalutamide: an open-label, phase 2, multicohort study. Lancet Oncol. 2018;19(1):76-86.

32. Schweizer MT, Wang $H$, Luber B, Nadal R, Spitz A, Rosen DM, et al. Bipolar Androgen Therapy for Men With Androgen Ablation Naïve Prostate Cancer: Results From the Phase II BATMAN Study. Prostate. 2016;76(13):1218-26.

33. Zytiga(C) (abiraterone acetate) Tablets. [Internet]. [cited 2018 Jul 24]. Available from: https:// google2.fda.gov/search?q=cache:Hb4GRrAl9K4J:www.accessdata.fda.gov/drugsatfda_docs/ nda/2013/202379orig1s006.pdf+abiraterone+approval+package\&client=FDAgov\&proxystylesheet=FDAgov\&output=xml_no_dtd\&site=FDAgov\&ie=UTF-8\&access=p\&oe=UTF-8

34. Drug Approval Package: BrandXtandi (enzalutamide) NDA \# 203415 [Internet]. [cited 2018 Jul 23]. Available from: https://www.accessdata.fda. gov/drugsatfda_docs/nda/2012/203415_xtandi_toc.cfm

35. Drug Approval Package: ERLEADA (apalutamide) [Internet]. [cited 2018 Jul 24]. Available from: https://www.accessdata.fda.gov/drugsatfda_ docs/nda/2018/erleada_210951_toc.cfm

36. Finn RS, Martin M, Rugo HS, Jones S, Im SA, Gelmon $\mathrm{K}$, et al. Palbociclib and Letrozole in Advanced Breast Cancer. N Eng J Med. 2016;375(20):1925-36.

37. McLornan DP, List A, Mufti GJ. Applying synthetic lethality for the selective targeting of cancer. $\mathrm{N}$ Eng J Med. 2014;371(18):1725-35. 